\title{
COVID-19 and the uniqueness of South Africa
}

\begin{tabular}{|c|c|}
\hline \multicolumn{2}{|c|}{$\begin{array}{l}\text { Authors: } \\
\text { Jarrod Zamparini }{ }^{1,2} \\
\text { Jacqui Venturas }^{1,2} \\
\text { Nina Diana }\end{array}$} \\
\hline \multicolumn{2}{|c|}{$\begin{array}{l}\text { Affiliations: } \\
{ }^{1} \text { Division of Infectious } \\
\text { Diseases, Department of } \\
\text { Medicine, Charlotte Maxeke } \\
\text { Johannesburg Academic } \\
\text { Hospital, Johannesburg, } \\
\text { South Africa }\end{array}$} \\
\hline \multicolumn{2}{|c|}{$\begin{array}{l}{ }^{2} \text { Department of Internal } \\
\text { Medicine, Faculty of Health } \\
\text { Sciences, University of the } \\
\text { Witwatersrand, } \\
\text { Johannesburg, South Africa }\end{array}$} \\
\hline \multicolumn{2}{|c|}{$\begin{array}{l}{ }^{3} \text { Division of Nephrology, } \\
\text { Department of Medicine, } \\
\text { Charlotte Maxeke } \\
\text { Johannesburg Academic } \\
\text { Hospital, Johannesburg, } \\
\text { South Africa }\end{array}$} \\
\hline \multicolumn{2}{|c|}{$\begin{array}{l}\text { Corresponding author: } \\
\text { Jacqui Venturas, } \\
\text { jpventuras@gmail.com }\end{array}$} \\
\hline \multicolumn{2}{|c|}{$\begin{array}{l}\text { How to cite this article: } \\
\text { Zamparini J, Venturas J, } \\
\text { Diana N. COVID-19 and the } \\
\text { uniqueness of South Africa. } \\
\text { S Afr J Infect Dis. 2020;35(1), } \\
\text { a208. https://doi.org/10. } \\
\text { 4102/sajid.v35i1.208 }\end{array}$} \\
\hline \multicolumn{2}{|c|}{$\begin{array}{l}\text { Copyright: } \\
\text { (C) 2020. The Authors. } \\
\text { Licensee: AOSIS. This } \\
\text { is licensed under the } \\
\text { Creative Commons } \\
\text { Attribution License. }\end{array}$} \\
\hline \multicolumn{2}{|l|}{ Read online: } \\
\hline 回战回 & $\begin{array}{l}\text { Scan this QR } \\
\text { code with your } \\
\text { smart phone or } \\
\text { mobile device } \\
\text { to read online. }\end{array}$ \\
\hline
\end{tabular}

Severe acute respiratory syndrome coronavirus 2 (SARS-CoV-2), a bat-borne betacoronavirus, was first identified in December 2019 from bronchoalveolar lavage specimens obtained from five patients in Wuhan, China who presented with severe community-acquired pneumonia of unknown aetiology. ${ }^{1}$ In February 2020, the disease caused by this virus was designated COVID-19. The number of cases spread rapidly throughout the world and was labelled a pandemic by the World Health Organization (WHO) on 11 March 2020, with the first case in South Africa reported on 5 March 2020 in a traveller returning from Italy. To date there have been 10,015 cases in South Africa and 194 deaths. ${ }^{2}$

The presentation of COVID-19 resembles a mild flu-like illness in the majority of patients (81\%). Severe disease is seen in $14 \%$ and critical disease (including acute respiratory distress syndrome [ARDS], multiorgan dysfunction and shock) in 5\%. ${ }^{3}$ Presentation in the pneumonic stage of COVID-19 is clinically similar to other causes of severe community-acquired pneumonia. In the South African population Streptococcus pneumoniae, influenza virus, Mycobacterium tuberculosis and Pneumocystis jirovecii should also be considered. ${ }^{4}$ Importantly, co-infection with other respiratory viruses has been reported to be up to $22 \%$ in an American case series, ${ }^{5}$ with reports from China indicating 50\% co-infection with other respiratory bacteria and viruses. ${ }^{6}$ In Wuhan, $87 \%$ of cases occurred in the 30 to 79 year age group, with an overall case fatality rate (CFR) of $2.3 \%$. The CFR was significantly higher in patients $\geq 80$ years old $(14.8 \%)$ and in those with co-morbid disease, particularly cardiovascular disease $(10.5 \%)$, diabetes $(7.3 \%)$ and hypertension $(6 \%)^{3}$

Of concern, the South African adult population has high rates of hypertension $(26.9 \%)$ and diabetes (11.3\%). ${ }^{7}$ In addition to this, it is estimated that there are 7.97 million people in South Africa living with $\mathrm{HIV}^{8}$ (of which only $55 \%$ are virally suppressed) ${ }^{9}$ It is unclear what the effect of co-infection with HIV has on patients infected with SARS-CoV-2, and whether an anti-retroviral regimen that includes lopinavir/ritonavir may have a protective effect. A study from China reported similar rates of COVID-19 disease in HIV positive and HIV negative patients. ${ }^{10}$ In this cohort, disease outcome was related to age and other co-morbid disease, rather than CD4 count, HIV viral load and the anti-retroviral therapy.

Currently there is no specific treatment for COVID-19. Most guidelines recommend supportive therapy with oxygen, empiric broad-spectrum antibiotics and antipyretics. Specific agents tried include remdesivir, chloroquine, azithromycin, lopinavir/ritonavir, interferon, intravenous immunoglobulin, corticosteroids, IL-6 inhibitors (Tocilizumab) and IL-1 inhibitors (Anakinra). Evidence is based on in-vitro and observational studies. The only randomised controlled trial using lopinavir and ritonavir (approved for the treatment of HIV infection) showed no difference in the time to resolution of symptoms. ${ }^{2}$

A large number of trials for a specific SARS-CoV-2 vaccine are ongoing. ${ }^{11}$ In the meantime interest has developed surrounding the possibility that the tuberculosis vaccine, BCG (Bacille Calmette Guerin) may induce 'trained immunity' by epigenetic remodelling, which would alter immune responsiveness to viral infections. It has been suggested that COVID-19 seems to be worse in countries with an absent or more recent BCG vaccination policy. ${ }^{12} \mathrm{~A}$ prospective trial is under way in Australia to determine whether BCG vaccination reduces the incidence and severity of COVID-19. ${ }^{13}$ BCG has been part of the immunisation schedule in South Africa since 1973; this may offer an element of protection. ${ }^{14}$

In South Africa, COVID-19 also raises socioeconomic concerns. Approximately 5.5 million people live in densely populated informal settlements where 'social distancing' is difficult, if not impossible. Overall only $74.2 \%$ of South Africans have access to water in their houses or on their properties; this number is even lower (40.4\%) in rural areas, which means that regular handwashing may be unrealistic in these communities. ${ }^{8}$ In addition, the ratio of doctors and nurses per person 
is far lower than many European countries that have been hardest hit by the COVID-19 outbreak. In 2017 in South Africa there was one doctor per 1111 people and one nurse per 284 people, 4.5 and 1.6 times less than Italy, which has one of the highest case fatality rates to date. ${ }^{15}$

COVID-19 has spread rapidly across the globe, affecting nearly every country and plunging the world into a state of pandemic not seen in more than a century. It has invaded every facet of our connected lives and is foremost in the mind of every clinician and citizen. Despite this, we must be cognisant of the need not to neglect other diseases and comorbidities during this time. We have the advantage of being able to see how the pandemic has unfolded in the rest of the world, allowing us to learn from their clinical and political response. The South African government enacted an early lockdown, in the hope of flattening the curve and avoiding a collapse of its already stretched healthcare services. Lessons learnt in terms of management, both clinical and logistic, have allowed us to prepare as best as we can.

\section{Acknowledgements Competing interests}

The authors have declared that no competing interests exist.

\section{Authors' contributions}

All authors contributed equally to this work.

\section{Ethical considerations}

This article followed all ethical standards for carrying out research without direct contact with human or animal subjects.

\section{Funding information}

This research received no specific grant from any funding agency in the public, commercial, or not-for-profit sectors.

\section{Data availability statement}

Data sharing is not applicable to this article as no new data were created or analysed in this study.

\section{Disclaimer}

The views and opinions expressed in this article are those of the authors and do not necessarily reflect the official policy or position of any affiliated agency of the authors.

\section{References}

1. Ren $\mathrm{L}-\mathrm{L}$, Wang $\mathrm{Y}-\mathrm{M}, \mathrm{Wu} \mathrm{Z}-\mathrm{Q}$, et al. Identification of a novel coronavirus causing severe pneumonia in human: A descriptive study. Chin Med J (Engl) [serial online] 2020 Mar 27 [cited 2020 Mar 31];Publish Ahead of Print. Available from: https:// journals.Iww.com/cmj/Abstract/publishahead/Identification_of_a_novel_ coronavirus causing.99423.aspx

2. COVID-19 technical resources [homepage on the Internet]. NICD. [cited $2020 \mathrm{Apr}$ 08]. Available from: https://www.nicd.ac.za/diseases-a-z-index/covid-19/covid19-resources/

3. Wu Z, McGoogan JM. Characteristics of and important lessons from the coronavirus disease 2019 (COVID-19) outbreak in China: Summary of a report of 72314 cases from the Chinese Center for Disease Control and Prevention. JAMA [serial online]. $2020 \mathrm{Feb} 24$ [cited $2020 \mathrm{Apr}$ 06]. Available from: https:// jamanetwork.com/journals/jama/fullarticle/2762130

4. South African Thoracic Society, Federation of Infectious Diseases Societies of Southern Africa, Boyles TH, Brink A, et al. South African guideline for the management of community-acquired pneumonia in adults. J Thorac Dis. 2017 management of community-acquired pneumonia in adults. J Thor
Jun;9(6):1469-1502. https://doi.org/10.21037\%2Fjtd.2017.05.31

5. Shah N. Higher co-infection rates in COVID19 [serial online]. Medium. 2020 [cited 2020 Apr 07]. Available from: https://medium.com/@nigam/higher-co-infectionrates-in-covid19-b24965088333

6. Zhang W. COVID-19 webcast fighting global covid-19 together: Clinical experience sharing and discussion. AstraZeneca. [cited 2020 Mar 28]. Available from: http// webstreamlive.com/astrazeneca/global/280320

7. GHO | By category | Risk factors [homepage on the Internet]. WHO. [cited 2020 Apr 08]. Available from: https://apps.who.int/gho/data/node.main.A867? lang=en

8. Publications | Statistics South Africa [homepage on the Internet]. [cited 2020 Apr 08]. Available from: http://www.statssa.gov.za/?page_id=1859

9. Johnson LF, Dorrington RE. Modelling the impact of HIV in South Africa's provinces: 2019 update. Cent Infect Dis Epidemiol Res Work Paper [serial online]. 2019. Available from: https://thembisa.org/downloads

10. Q\&A on COVID-19, HIV and antiretrovirals [homepage on the Internet]. [cited 2020 Apr 07]. Available from: https://www.who.int/news-room/q-a-detail/q-aon-covid-19-hiv-and-antiretrovirals

11. Treatment of Coronavirus Disease 2019 (COVID-19): Investigational drugs and other therapies: Introduction, investigational antiviral agents, immunomodulators and other investigational therapies [homepage on the Internet]. $2020 \mathrm{Apr} 04$ [cited $2020 \mathrm{Apr}$ 07]. Available from: https://emedicine.medscape.com/ article/2500116-overview\#a4

12. Miller A, Reandelar MJ, Fasciglione K, Roumenova V, Li Y, Otazu GH. Correlation between universal BCG vaccination policy and reduced morbidity and mortality for COVID-19: An epidemiological study. medRxiv. 2020 Mar 28;2020. 03.24.20042937.

13. BCG vaccination to protect healthcare workers against COVID-19 - Full text view ClinicalTrials.gov [homepage on the Internet]. [cited 2020 Apr 07]. Available from: https://clinicaltrials.gov/ct2/show/NCT04327206

14. Hesseling AC, Caldwell J, Cotton MF, et al. BCG vaccination in South African HIVexposed infants - Risks and benefits. South Afr Med J. 2009 Feb;99(2):88-91.

15. Physicians (per 1,000 people) - Italy, South Africa | Data [homepage on the Internet]. [cited 2020 Mar 31]. Available from: https://data.worldbank.org/ indicator/SH.MED.PHYS.ZS?locations=IT-ZA 